\title{
Diosmin induces caspase-dependent apoptosis in human glioblastoma cells
}

\section{JULIANA M. SOARES ${ }^{1,2}$, BRUNA M. DE FARIA ${ }^{1}$, LUCAS M. ASCARI ${ }^{2}$, SONIZA V. ALVES-LEON ${ }^{3}$, JORGE M. DE SOUZA ${ }^{3}$, ANTONIO G. SOARES ${ }^{4}$, YRAIMA CORDEIRO ${ }^{2}$ and LUCIANA F. ROMÃO ${ }^{1}$}

\author{
${ }^{1}$ Instituto de Ciências Biomédicas, Universidade Federal do Rio de Janeiro, Av. Carlos \\ Chagas Filho, 373, CCS, B1. F026, 21941-590 Rio de Janeiro, RJ, Brazil \\ ${ }^{2}$ Faculdade de Farmácia, Universidade Federal do Rio de Janeiro, Av. Carlos Chagas \\ Filho 373, CCS, B1. Bss 17, 21941-902 Rio de Janeiro, RJ, Brazil \\ ${ }^{3}$ Hospital Universitário Clementino Fraga Filho, Universidade Federal do Rio de Janeiro, \\ Rua Prof. Rodolpho Paulo Rocco, 255, 21941-590 Rio de Janeiro, RJ, Brazil \\ ${ }^{4}$ Empresa Brasileira de Pesquisa Agropecuária/EMBRAPA, Centro Nacional de Pesquisa de Tecnologia \\ Agroindustrial de Alimentos, Av. das Américas, 29501, 23020-470 Rio de Janeiro RJ, Brazil \\ Manuscript received on August 31, 2019; accepted for publication on October 23, 2019
}

\begin{abstract}
How to cite: SOARES JM, FARIA BM, ASCARI LM, ALVES-LEON SV, SOUZA JM, SOARES AG, CORDEIRO Y AND ROMÃO LF. 2019. Diosmin induces caspase-dependent apoptosis in human glioblastoma cells. An Acad Bras Cienc 91: e20191031. DOI 10.1590/0001-3765201920191031.
\end{abstract}

\begin{abstract}
Diosmin is a flavone glycoside clinically used as the main component of Daflon for the treatment of venous diseases. Several studies demonstrated that this natural compound can induce apoptosis in different tumors. However, isolated diosmin has not been studied regarding its effects on glioblastoma so far. Since glioblastoma is a highly lethal and fast-growing brain tumor, new therapeutic strategies are urgently needed. Herein, we evaluated the role of this flavonoid against glioblastoma cells using in vitro assays. Diosmin significantly reduced the viability of GBM95, GBM02, and U87MG glioblastoma cells, but not of healthy human astrocytes, as verified by MTT assay. Vimentin immunostaining showed that diosmin induced morphological changes in GBM95 and GBM02 cells, making them smaller and more polygonal. Diosmin did not inhibit GBM95 and GBM02 cell proliferation, but it caused DNA fragmentation, as verified by the TUNEL assay, and increased cleaved caspase-3 expression in these cells. In summary, diosmin is able to induce caspase-dependent apoptosis specifically in tumor cells and, therefore, could be considered a promising therapeutic compound against glioblastoma.
\end{abstract}

Key words: apoptosis, diosmin, flavonoid, glioblastoma.

\section{INTRODUCTION}

Glioblastoma, a malignant brain tumor, is characterized by rapid cell proliferation, high parenchyma infiltration, and angiogenesis. Due to its fast evolution and morphological heterogeneity,

Correspondence to: Luciana Ferreira Romão

E-mail: romao@icb.ufrj.br

ORCID: https://orcid.org/0000-0002-8560-4983 glioblastoma is very aggressive (Maher et al. 2001). Currently, the treatment consists in surgical removal followed by radiation and chemotherapy, mainly with temozolomide (TMZ) (Würth et al. 2014). In addition to TMZ, bevacizumab is also indicated to treat recurrent glioblastoma, but, to date, no significant impact on overall survival upon treatment with this monoclonal antibody has been achieved (Mooney et al. 2019). Despite 
therapeutic advances, glioblastoma is still lethal, as the median survival is 15 to 18 months for newly diagnosed patients, and around $10 \%$ survive 5 years (Lieberman 2017).

Since current therapies are not effective in curing and/or significantly expanding life expectancy of glioblastoma-affected patients, the search for new therapeutic approaches is intensifying. In this context, natural compounds, such as flavonoids, are emerging as alternatives for treating different types of tumors with reduced side effects (Ali et al. 2012, Chen et al. 2016b, Sak 2014). Flavonoids, polyphenolic compounds found in fruits and vegetables, have been described as presenting various biological and pharmacological effects (Chahar et al. 2011, Chen et al. 2016b, Sak 2014). In vitro and in vivo studies have suggested that they can influence different phases of the cell cycle and can modulate tumor progression by inhibiting proliferation and/or inducing cell death (Chen et al. 2016a, Fantini et al. 2015, Srinivasan and Pari 2012).

Several works have reported the activity of flavonoids against different cell lines of human glioblastoma. Among these flavonoids, are the flavones apigenin, luteolin, and chrysin (Chakrabarti and Ray 2015, Chen et al. 2016b, Das et al. 2010, Kim et al. 2016, Santos et al. 2015, Stump et al. 2017); the flavonols quercetin and kaempferol (Kim et al. 2016, Santos et al. 2015); the flavanones naringenin and hesperetin ( $\mathrm{Li}$ et al. 2017, 2019); and the isoflavones genistein and daidzein (Das et al. 2010, Siegelin et al. 2009). A recent review pointed out the capacity of different flavonoids to reduce glioblastoma cell proliferation and to induce apoptosis (Erices et al. 2018).

Diosmin (3',5,7-trihydroxy-4' -methoxyflavone 7-rutinoside) is a flavonoid glycoside constituted by a flavone named diosmetin (3',5,7-trihydroxy4'-methoxyflavone), a unit of glucose, and a unit of rhamnose (Fig. 1). This molecule is reported to have anti-inflammatory and vascular protective effects due to its ability to inhibit prostaglandin and thromboxane synthesis (El-Shafae and ElDomiaty 2001, Hitzenberger 1997, Laurent et al. 1988, Srinivasan and Pari 2012). Diosmin is already commercially available in the formulation of Daflon for treating chronic venous diseases, for which it is considered to be very effective (Ramelet 2001). This drug is also highly safe for both animals and humans (Meyer 1994).

Previous works have shown that diosmin also displays antitumor activity, such as in pulmonary melanoma (Álvarez et al. 2009), prostate cancer (Lewinska et al. 2015), breast cancer (Lewinska et al. 2017), and hepatocellular carcinoma (Dung et al. 2012, Perumal et al. 2018). Other studies have reported the antitumor effect of the isolated aglycone form of diosmin (i.e., diosmetin), such as in human colon cancer (Koosha et al. 2019), skin cancer (Choi et al. 2019), and breast cancer (Wang et al. 2019). These works demonstrated that diosmin/diosmetin acts via different mechanisms, such as G2/M cell cycle arrest, oxidative stress, apoptosis, and expression of tumor suppressant genes.

In a recent study, diosmin was identified in ethanolic extracts from Phlomis viscosa leaves, and treatment of U87MG cells with the whole plant extract significantly reduced cell viability (Yarmolinsky et al. 2019). However, there are no reports on whether isolated diosmin (or its

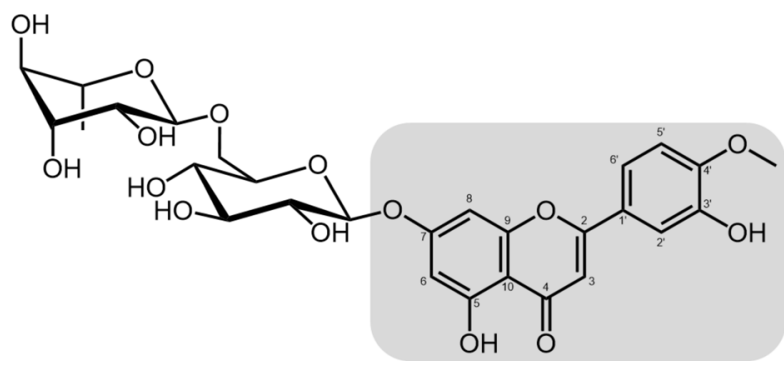

Figure 1 - Chemical structure of diosmin (diosmetin 7-O-rutinoside). The highlighted portion corresponds to the flavone constituent, which is bound to a unit of glucose, which in turn is bound to a unit of rhamnose. 
aglycone diosmetin), like other flavones, also acts against glioblastoma. Thus, in the present study, we investigated the effects of diosmin against glioblastoma by analyzing the viability, proliferation, and morphology of different tumor cell lines. We also evaluated whether diosmin affects the viability of healthy astrocytes to ensure it has cell-specific effects.

\section{MATERIALS AND METHODS}

\section{GLIOBLASTOMA CELL CULTURE}

Human glioblastoma cell lines GBM95 and GBM02 were obtained from patients at Clementino Fraga Filho Hospital (HUCFF), at the Federal University of Rio de Janeiro (UFRJ), and were characterized by our group using histological and immunocytochemistry assays (Ethics Committee, CONEP 2340) (Faria et al. 2006). Human glioblastoma cell line U87MG was acquired from ATCC (Washington DC, USA). All cells were grown and maintained in 100-mm culture flasks (TPP, Switzerland) containing Dulbecco`s modified Eagle`s medium (DMEM-F12, Sigma, St. Louis) supplemented with $10 \%(\mathrm{v} / \mathrm{v})$ fetal bovine serum (FBS, GIBCO BRL, Grand Island, NY), $3.5 \mathrm{mg} /$ $\mathrm{mL}$ glucose, $0.1 \mathrm{mg} / \mathrm{mL}$ penicillin, and $0.14 \mathrm{mg} /$ $\mathrm{mL}$ streptomycin. Culture flasks were maintained at $37^{\circ} \mathrm{C}$ in an atmosphere of $5 \% \mathrm{CO}_{2}$ and $95 \%$ air. Whenever cells reached confluence, they were detached by trypsinization and centrifuged at 1,500 rpm. Cells were resuspended in DMEM-F12 for subsequent assays.

\section{HUMAN ASTROCYTE CELL CULTURE}

Adult primary human astrocyte cells were obtained by surgical resection of the anterior temporal lobe tissue from patients selected for surgical treatment at HUCFF (Ethics Committee, CONEP 2340). Only healthy cortical tissue was used to produce astrocyte cultures. Human astrocyte cells were cultured in flasks with DMEM-F12 supplemented with $10 \%$ FBS and maintained at $37{ }^{\circ} \mathrm{C}$ in an atmosphere of $5 \% \mathrm{CO}_{2}$ and $95 \%$ air. Cells were characterized by the expression of typical astrocyte markers (Garcia et al. 2014). Whenever cells reached confluence, they were detached from the flasks by trypsinization, centrifuged at $1500 \mathrm{rpm}$ and resuspended in DMEM-F12 for subsequent assays.

\section{ETHICS APPROVAL}

All applicable international, national, and/ or institutional guidelines were followed. This article does not contain any studies performed with animals. Procedures involving human cells were done in accordance with ethical standards approved in July $9^{\text {th }}, 2001$ by The Brazilian National Commission of Ethics \& Research (CONEP 2340).

EXTRACTION, PURIFICATION, AND

CHARACTERIZATION OF DIOSMIN

Diosmin (3', 5,7-trihydroxy-4'-methoxyflavone 7 -rutinoside) was extracted from orange peels with methanol. The extraction was cheaper than the commercial diosmin sample. In addition, it allowed us to use a natural resource to extract diosmin, avoiding orange peel waste and allowing its use for a possible therapeutic function. The orange peel samples were dehydrated in a forced air oven at $55{ }^{\circ} \mathrm{C}$ for 8 hours. To perform the extraction, $100 \mathrm{~g}$ of dried orange peel powder were weighted and then $100 \mathrm{~mL}$ of $80 \%$ methanol was added. The sample was placed in an ultrasound equipment for assisted extraction $(60 \mathrm{kHz}$ for 30 $\min$ at $40{ }^{\circ} \mathrm{C}$ ). After the extraction, methanol was evaporated in a condenser. Then, $2 \mathrm{M} \mathrm{NaOH}$ was used as basifying agent and water was used as solvent. Afterwards, acetic acid was added until the medium $\mathrm{pH}$ reached 7 for diosmin precipitation. The resulting mixture was centrifuged to obtain the diosmin pellet, which was lyophilized for 24 hours until the sample was completely dry. The yield was approximately $4.45 \mathrm{mg}$ per $100 \mathrm{~g}$ of orange 
peel powder. The diosmin sample was dissolved in dimethyl sulfoxide/methanol and filtered using a $0.45-\mu \mathrm{m}$ nylon membrane. Then, it was purified by high-performance liquid chromatography (HPLC). The structural characterization of the product was performed by nuclear magnetic resonance (NMR). Diosmin samples had a purity of over $96 \%$. The extraction, purification, and characterization were conducted at the Laboratory of Post-harvest Physiology of Fruits and Vegetables at Brazilian Agricultural Research Corporation (EMBRAPA, Brazil).

\section{CELL TREATMENT WITH DIOSMIN AND TEMOZOLOMIDE (TMZ)}

Lyophilized diosmin was dissolved in dimethyl sulfoxide (DMSO, Sigma-Aldrich, Inc) to prepare a $50 \mathrm{mM}$ stock solution, which was stored at 4 ${ }^{\circ} \mathrm{C}$. Temozolomide (TMZ, Sigma-Aldrich, Inc) was dissolved in DMSO to prepare a $50 \mathrm{mM}$ stock solution, which was stored at $-20{ }^{\circ} \mathrm{C}$. Before treating cells, diosmin and TMZ were diluted in DMEM-F12 medium supplemented with 10\% FBS to reach the final desired concentrations. GBM95, GBM02, U87MG, and human astrocyte cells were cultured for 24 hours in 96-well tissue culture plates (TPP, Switzerland) containing DMEM-F12 supplemented with $10 \%$ FBS. Cells were treated for 24 and 48 hours with diosmin at 10, 50, 75, 100 , and $150 \mu \mathrm{M}$. These treatment times and concentrations were selected based on previous studies with the flavones luteolin and apigenin (Chakrabarti and Ray 2015, Stump et al. 2017). GBM95 and GBM02 cells were also treated with TMZ at 50,100, and $200 \mu \mathrm{M}$ and with diosmin at 50 or $100 \mu \mathrm{M}$ in combination $200 \mu \mathrm{M}$ TMZ. The controls contained the same residual amount of DMSO as the samples.

MTT ASSAY

The 3-(4,5-dimethyl-2-thiazolyl)-2,5-diphenyl2H-tetrazolium bromide (MTT, Sigma-Aldrich,
Inc) colorimetric method was used to determine glioblastoma and astrocyte cell viability. After treatments, cells were incubated with $5 \mathrm{mg} / \mathrm{mL}$ MTT for 2 hours. The reaction product, formazan, was dissolved in DMSO. The amount of formazan was quantified at $570 \mathrm{~nm}$ using a Victor 3 Perkin Elmer UV spectrophotometer.

\section{EdU ASSAY}

The Click-iT EdU Alexa Fluor 488 imaging kit (Invitrogen Corporation) was used to evaluate glioblastoma cell proliferation after diosmin treatment (at 50 and $100 \mu \mathrm{M}$ ) for 48 hours. GBM95 and GBM02 cells were cultured in 24-well tissue culture plates (TPP, Switzerland) with $13-\mathrm{mm}$ cover slips (Knittel Glass, Germany) for 24 hours with DMEM-F12 containing 10\% FBS. After 42 hours, EdU was added to the treatment medium and incubated for 6 hours. Cells were then fixed with 4\% formaldehyde solution and incubated at room temperature with EdU detection cocktail. Subsequently, Hoechst 33342 dye (Thermo Fisher Scientific) was used for nucleus staining. All reagents and kit components were diluted and stored according to the manufacturer's protocol. Proliferative cells stained by EdU were imaged by fluorescence microscopy (Nikon TE 300) and counted using ImageJ software (version $1.44 \mathrm{p}$, Wayne Rasband National Institutes of Health, USA). Three independent experiments were performed in duplicate, and ten randomized images were analyzed.

\section{TUNEL ASSAY}

Cell death was evaluated by the In Situ Cell Death Detection, TMR red kit (TUNEL, Life Science Roche). GBM95 and GBM02 cells were cultured in 24-well tissue culture plates (TPP, Switzerland) with $13 \mathrm{~mm}$ cover slips for 24 hours with DMEM-F12 supplemented with $10 \%$ FBS. After treatment with diosmin (at 50 and $100 \mu \mathrm{M}$ ) for 24 and 48 hours, 
cells were fixed with $4 \%$ formaldehyde solution and permeabilized with $0.1 \%$ Triton X-100 (SigmaAldrich, Inc) and $0.1 \%$ sodium citrate solution. The dUTP reagent was incubated for one hour at $37^{\circ} \mathrm{C}$. All reagents and kit components were diluted and stored according to the manufacturer's protocol. DAPI (4',6-diamidino-2-phenylindole) was used for nucleus staining. Dead cells were imaged by fluorescence microscopy (Nikon TE 300) and counted by ImageJ software (version $1.44 \mathrm{p}$, Wayne Rasband National Institutes of Health, USA). Three independent experiments were performed in duplicate, and ten randomized images were analyzed.

\section{IMMUNOCYTOCHEMISTRY}

GBM95 and GBM02 cells were cultured in 24well tissue culture plates (TPP, Switzerland) with $13 \mathrm{~mm}$ cover slips and cultured for 24 hours with DMEM-F12 supplemented with 10\% FBS. Cells were treated with diosmin (at 50 and $100 \mu \mathrm{M}$ ) for 24 and 48 hours at $37{ }^{\circ} \mathrm{C}$. After treatment, cells were fixed with $4 \%$ formaldehyde solution. Fixed cells were permeabilized with $0.1 \%$ Triton X-100 (Sigma-Aldrich, Inc) and blocked with 5\% bovine serum albumin solution (BSA, Sigma-Aldrich, Inc). To detect intermediate filaments, cells were incubated overnight with Monoclonal Mouse Anti-Vimentin Clone V9 (Dako Agilent Pathology Solutions) at $4{ }^{\circ} \mathrm{C}$ and then incubated with Alexa Fluor 546 goat anti-mouse IgG (Thermo Fisher Scientific) at room temperature. To detect apoptosis, cells were incubated overnight with cleaved caspase-3 (Cell Signaling Technology) at $4{ }^{\circ} \mathrm{C}$ and subsequently incubated with Alexa Fluor 488 goat anti-rabbit IgG (Thermo Fisher Scientific) and DAPI dye at room temperature. After that, cells were examined by fluorescence microscope (Nikon TE 300) and analyzed using ImageJ software (version $1.44 \mathrm{p}$, Wayne Rasband National Institute of Health, USA).

\section{MORPHOLOGICAL ANALYSIS}

The morphology and total number of glioblastoma cells were analyzed after diosmin treatment (at 50 and $100 \mu \mathrm{M}$ ) for 24 and 48 hours. Cytoskeleton changes were assessed using ImageJ (software $1.44 \mathrm{p}$, Wayne Rasband National Institute of Health, USA) by measuring the length of vimentin-stained cells. The length of treated cells was compared to the length of control cells treated with DMSO. ImageJ was also used to count glioblastoma cell nuclei. The total number of cells was assessed by the percentage of DAPI positive cells in comparison to control. Three independent experiments were performed in duplicate, and ten randomized images were analyzed.

\section{STATISTICAL ANALYSIS}

Statistical analyses were executed in GraphPad Prism (version 7.0, California, USA). All values were expressed as mean \pm SEM. Data were analyzed by one-way ANOVA followed by post hoc comparison (Tukey's test). Statistical significance was set at $* \mathrm{p}<0.05 ; * * \mathrm{p}<0.01 ; * * * \mathrm{p}<0.001$.

\section{In Silico PHARMACOKINETIC EVALUATION}

The chemical structure of diosmetin, the aglycone form of diosmin, was drawn using ChemDraw (version Ultra 12.0). Several in silico analyses of physicochemical and pharmacokinetic properties were performed on ADMET Predictor ${ }^{\mathrm{TM}}$ software (version 9.0, Simulations Plus, CA). The parameters analyzed were molar weight ( $\mathrm{MW}, \mathrm{g} / \mathrm{mol}$ ), octanol/water partition coefficient $(\log \mathrm{P})$, octanol/ water distribution coefficient at pH $7.4(\log \mathrm{D})$, topological polar surface area (TPSA), number of hydrogen bond donors (HBD), the ionization constant ( $\mathrm{pKa}$ ) for the most basic center, brain penetration (BP), brain/blood partition coefficient $(\log B B)$, and the probability of being Pgp substrate (PgpS). Regarding the accuracy of such analyses, 
this software presents reliable statistical data for all its models ( $\mathrm{r}^{2}$ of $\sim 0.9$ to 0.7 ).

\section{RESULTS}

DIOSMIN REDUCES GLIOBLASTOMA CELL VIABILITY, BUT DOES NOT REDUCE ASTROCYTE VIABILITY

Previous studies demonstrated that diosmin decreases the viability of hepatic carcinoma and prostate cancer cells (Dung et al. 2012, Lewinska et al. 2015). To evaluate its effects on the viability of glioblastoma cells and healthy astrocytes, the MTT colorimetric assay was performed. GBM95, GBM02, U87MG, and astrocyte cells were incubated with diosmin at 10, 50, 75, 100, and $150 \mu \mathrm{M}$ for 24 and 48 hours. These treatment times and concentrations were selected based on previous studies with flavonoids, such as luteolin and apigenin, which belong to the same flavonoid class as that of diosmin (Chakrabarti and Ray 2015, Stump et al. 2017). In relation to control, diosmin decreased GBM95 and GBM02 cell viability in almost all conditions. Even at the lowest concentration $(10 \mu \mathrm{M})$, diosmin was able to reduce glioblastoma cell viability. However, the intermediate concentrations (50 and $100 \mu \mathrm{M}$ ) provided more satisfactory results. GBM95 cells treated with diosmin at 50 and $100 \mu \mathrm{M}$ exhibited, respectively, a viability reduction of $50.6 \%$ and $54 \%$ after a 24 -hour treatment and $49.9 \%$ and $60.2 \%$ after a 48 -hour treatment (Fig. 2a). Under the same conditions, diosmin reduced GBM02 cell viability in $30 \%$ after a 24 -hour treatment and in $33 \%$ after a 48 -hour treatment (Fig. 2b). At the concentrations of 50 and $100 \mu \mathrm{M}$, diosmin reduced U87MG cell viability in $40 \%$, but this cytotoxicity was only seen after a 48-hour treatment (Fig. 2c). In summary, diosmin significantly decreased the viability of all three glioblastoma cell lines, acting as a cytotoxic compound.
Healthy astrocytes were also subjected to treatment with diosmin to assess whether the toxicity of this compound is cell-specific. We only observed a small decrease (less than $15 \%$ ) in astrocyte viability after diosmin treatment at the concentrations of 10 and $100 \mu \mathrm{M}$ for 48 hours (Fig. $2 \mathrm{~d})$. None of the other treatment conditions caused a significant decrease in astrocyte viability. This result indicates that diosmin was significantly more toxic against glioblastoma cells than for healthy astrocytes, highlighting diosmin cell-specific effects. The commercial and well-established U87MG cell line was used herein for comparison, and the following in vitro evaluations were conducted using only GBM95 and GBM02 cells, which have known origin and number of passages, since these cell lines have been fully characterized by our group (Faria et al. 2006). The U87MG cell line currently in use has mischaracterization issues, as it has been reported to have a different origin from that of the initial cell line established in 1968 (Allen et al. 2016).

DIOSMIN IN COMBINATION WITH TMZ IS MORE EFFECTIVE THAN ONLY TMZ IN REDUCING GLIOBLASTOMA VIABILITY

Our first analysis revealed that diosmin reduced glioblastoma cell viability. Therefore, we decided to evaluate whether a combination of diosmin with TMZ, the reference chemotherapeutic agent for glioblastoma treatment (Würth et al. 2014), would be better than the individual treatments. GBM95 and GBM02 cells were treated with diosmin at 50 and $100 \mu \mathrm{M}$ in combination with $200 \mu \mathrm{M} \mathrm{TMZ}$. Cells were also treated with TMZ at 50,100, and $200 \mu \mathrm{M}$. After a 48-hour treatment, TMZ alone at $200 \mu \mathrm{M}$ was able to reduce GBM95 and GBM02 cell viability by only $20 \%$ and $14 \%$, respectively (Fig. 3a,b). When we performed a 24-hour treatment with $50 \mu \mathrm{M}$ diosmin in combination with $200 \mu \mathrm{M}$ $\mathrm{TMZ}$, there was an approximate viability reduction of $23 \%$ and $16 \%$ for GBM95 and GBM02 cells, 

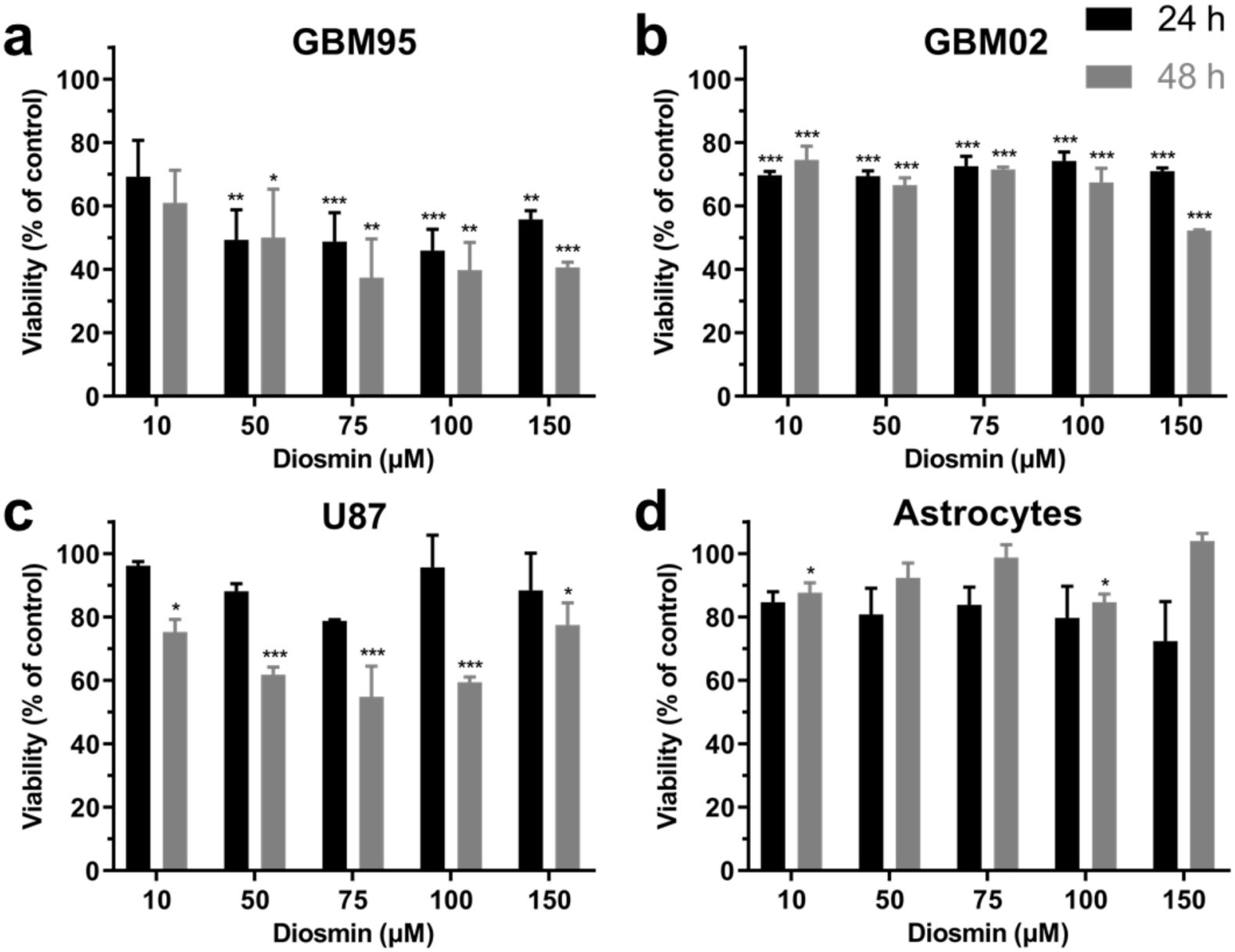

Figure 2 - Diosmin reduced the viability of GBM95, GBM02, and U87MG cells, but did not reduce the viability of human astrocytes. Cell viability was assessed by MTT reduction assay and expressed as percentage of viable cells, compared to control (DMSO residue). Glioblastoma cells and healthy human astrocytes were treated with diosmin for 24 and 48 hours at different concentrations (10 to $150 \mu \mathrm{M})$. Representative graphs of the viability of GBM95 (a), GBM02 (b), U87MG (c), and healthy human astrocytes (d). Significant viability reduction was observed in glioblastoma cells under almost all conditions. Results represent the mean \pm SEM of three independent experiments, each performed in triplicate $\left({ }^{*} \mathrm{p}<0.05 ; * * \mathrm{p}<0.01 ; * * * \mathrm{p}<0.001\right)$.

respectively. At the same concentrations, the 48hour treatment reduced the viability of both cell lines in 29\% (Fig. 3a,b). A 48-hour treatment of diosmin at $100 \mu \mathrm{M}$ combined with TMZ at $200 \mu \mathrm{M}$ decreased the viability of GBM95 and GBM02 cells in 25\% and 19\%, respectively (Fig. $3 a, b)$. These results showed that the association of diosmin and TMZ is more effective than only TMZ. Controversially, diosmin alone was more effective than TMZ and the combination of diosmin with $\mathrm{TMZ}$, indicating that there is no synergistic effect between these drugs.

\section{DIOSMIN REDUCES CELLULARITY AND PROMOTES MORPHOLOGICAL CHANGES IN GLIOBLASTOMA CELLS}

Cell size reduction is closely associated with cytotoxic effects, such as apoptosis (Elmore 2007). This type of morphological change in glioblastoma cells has been associated with treatment with flavonoids (Santos et al. 2015). To evaluate whether the cytotoxic effect of diosmin caused changes in glioblastoma cytoskeletal architecture, we analyzed vimentin, an intermediate filament protein, by immunocytochemistry. After diosmin 


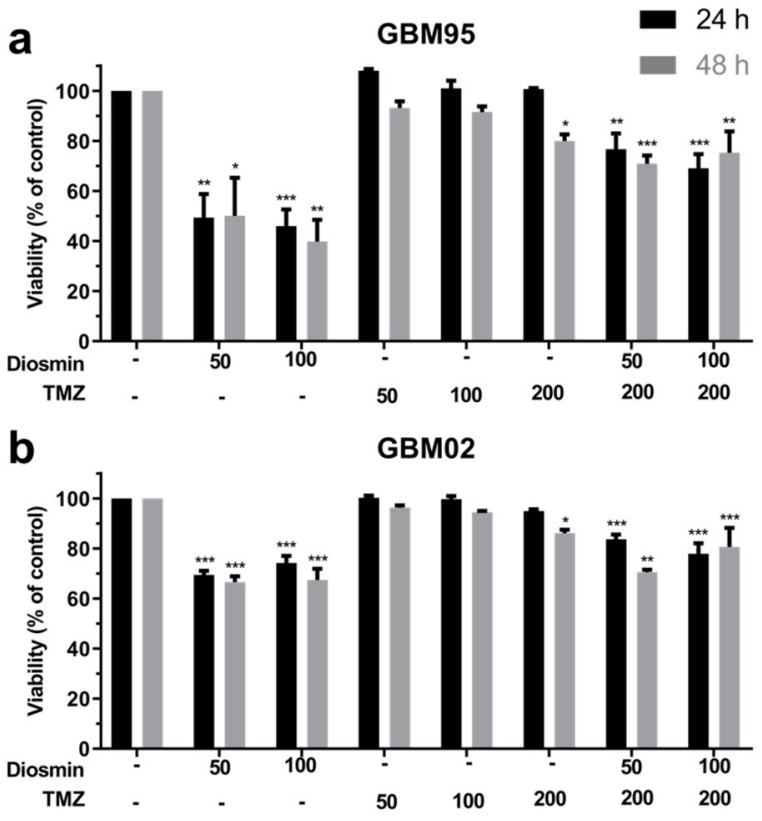

Figure 3 - Combination of diosmin and TMZ reduced cell viability without synergistic effect. Cell viability was assessed by MTT reduction assay. Graphs represent the percentage of viable cells, compared to the control (DMSO residue). Glioblastoma cells were treated for 24 and 48 hours with diosmin at 50, and $100 \mu \mathrm{M}$; TMZ at 50, 100, and $200 \mu \mathrm{M}$; and diosmin at $50 \mu \mathrm{M}$ or $100 \mu \mathrm{M}$ combined with $200 \mu \mathrm{M}$ TMZ. Representative graphs of the viability of GBM95 (a) and GBM02 (b) cells. Results represent mean \pm SEM of three independent experiments, each performed in triplicate $\left({ }^{*} \mathrm{p}\right.$ $<0.05 ; * * \mathrm{p}<0.01 ; * * * \mathrm{p}<0.001)$.

treatment (at 50 and $100 \mu \mathrm{M}$ ) for 24 and 48 hours, cells with a different phenotype could be observed, as they became smaller and more polygonal (Fig. $4 \mathrm{a}, \mathrm{b})$. However, no cytoplasmic retraction was seen in the controls (Fig. 4). Cell length measurements indicated that diosmin decreased the size of GBM95 and GBM02 cells. Diosmin reduced GBM95 length by more than $50 \%$ after a 24 -hour treatment and by almost $60 \%$ after a 48 -hour treatment (Fig. 4c). Diosmin also changed GBM02 morphology by reducing cell length in $50 \%$ after a 24 -hour treatment and in $27 \%$ after a 48 -hour treatment (Fig. 4e).

We also noticed a reduction in GBM95 and GBM02 cellularity. GBM95 culture exposed to diosmin (at 50 and $100 \mu \mathrm{M}$ ) for 24 hours underwent a significant reduction in cell number (40\%) (Fig. 4d). The 48-hour treatment significantly reduced the number of GBM95 cells (37.7\%) only at $50 \mu \mathrm{M}$. GBM02 cells treated with diosmin (at 50 and 100 $\mu \mathrm{M})$ for 24 and 48 hours underwent a cellularity decrease of more than 30\% (Fig. 4f). Our data indicate that diosmin decrease the population of GBM95 and GBM02 cells and induces their size reduction, suggesting a potential cytotoxic effect.

\section{DIOSMIN-INDUCED DECREASE IN GLIOBLASTOMA CELLULARITY IS NOT ASSOCIATED WITH REDUCED CELL PROLIFERATION}

According to previous reports, reduced cellularity may be associated with a decrease in cell proliferation (Ouhtit et al. 2013). Therefore, the Click-it EdU imaging kit was used to assess GBM95 and GBM02 cell proliferation after diosmin treatment (at 50 and $100 \mu \mathrm{M}$ ) for 48 hours; it was done by analyzing these cells at the DNA synthesis phase. At none of the concentrations tested, diosmin significantly decreased the number of proliferative cells in relation to control (Fig. 5), suggesting that diosmin-mediated reduction in cellularity was not linked to changes in the proliferation rate of glioblastoma cells.

\section{DIOSMIN INDUCES GLIOBLASTOMA CELL DEATH BY APOPTOSIS}

As the decrease in the viability and number of GBM95 and GBM02 cells was not associated with modifications in their proliferation rate, we hypothesized that it could be related to cell death. Morphological changes, such as cell shrinkage, were previously associated with apoptosis (Elmore 2007). Therefore, we analyzed cell death by DNA fragmentation using the TUNEL assay to confirm whether diosmin caused morphological changes and cytotoxic effects on glioblastoma cells. This evaluation showed an increase in GBM95 and GBM02 cell death after treatment with diosmin (at 

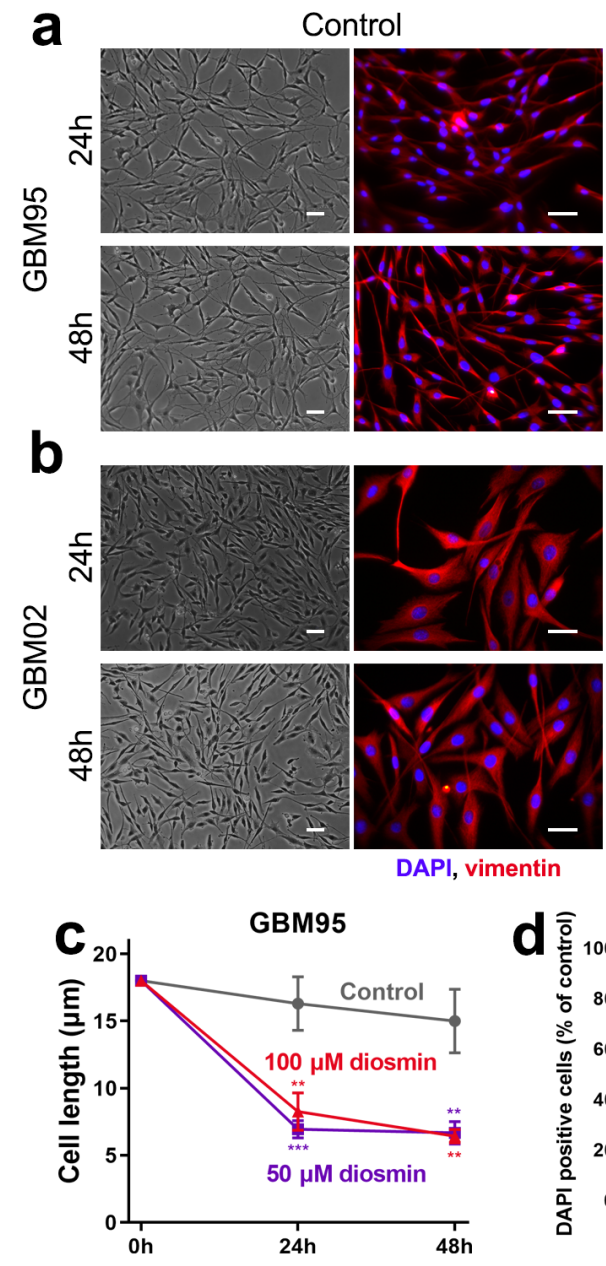
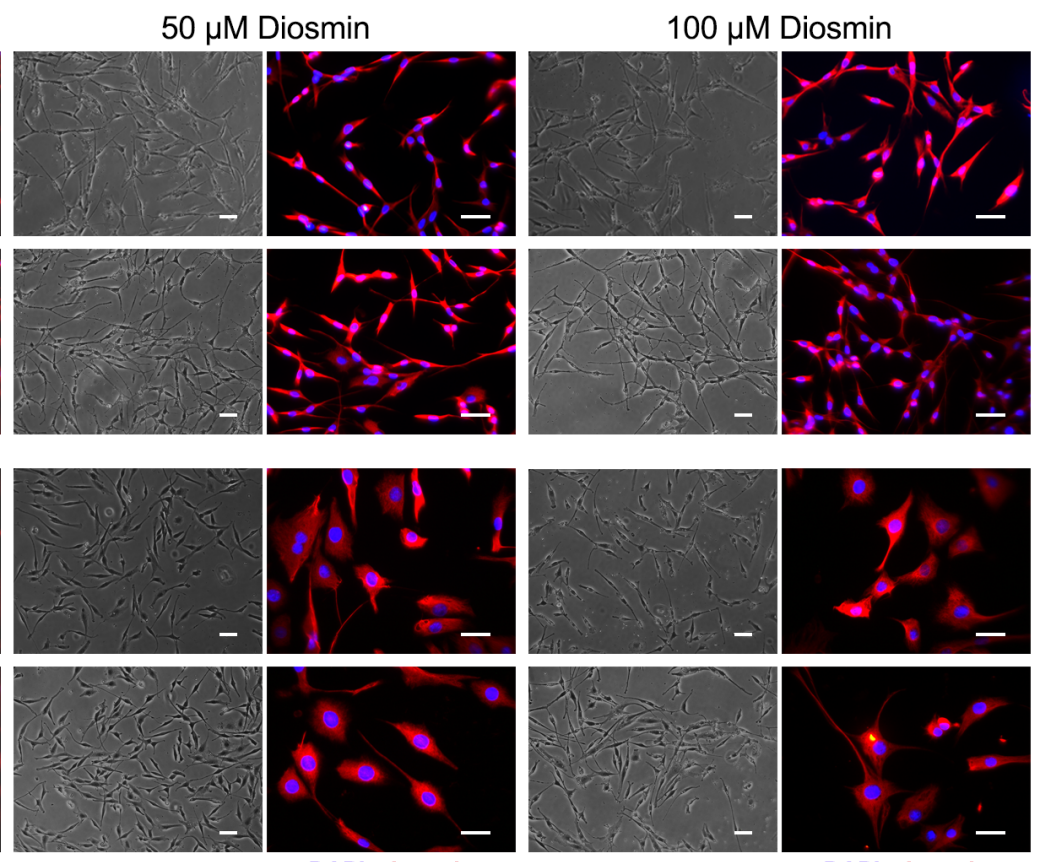

DAPI, vimentin
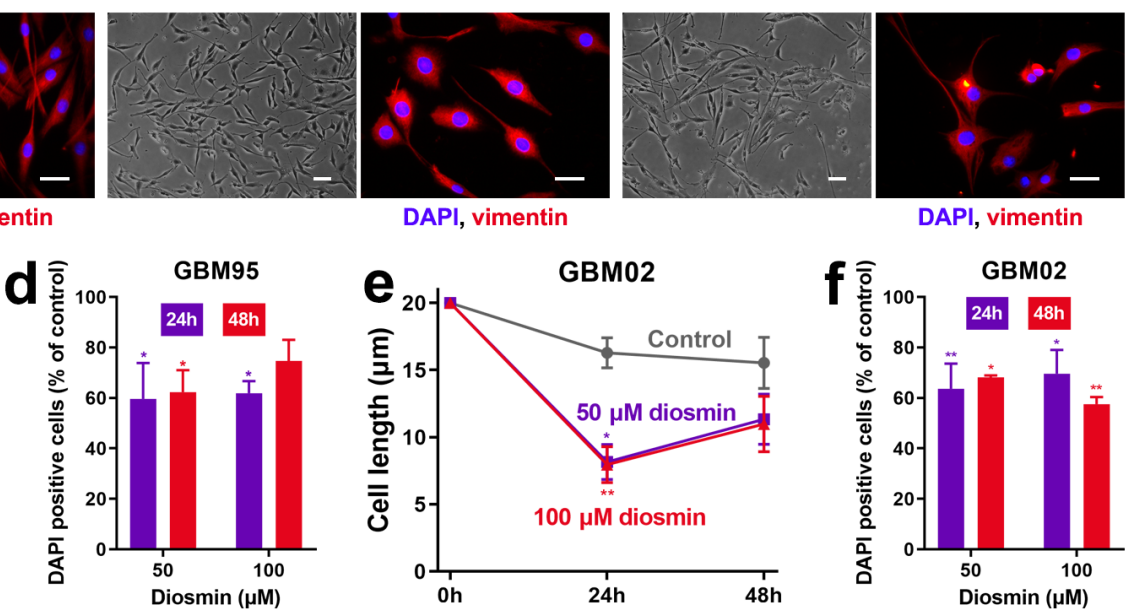

DAPI, vimentin

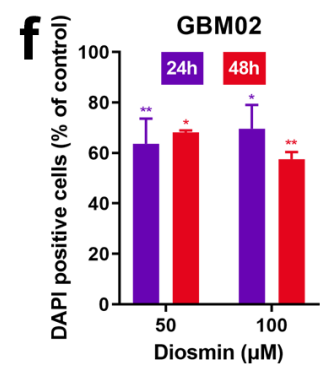

Figure 4 - Diosmin induced morphological alterations and reduced GBM95 and GBM02 cellularity. Phase contrast (gray scale) and vimentin immunostaining (red) were used to evaluate cell morphology and cytoskeleton. DAPI (blue) was used for nuclei staining to count the total number of cells. GBM95 and GBM02 were treated with diosmin (at 50 and $100 \mu \mathrm{M}$ ) for 24 and 48 hours. DMSO was used as control. Phase contrast and vimentin representative images of GBM95 (a) and GBM02 (b), representative graphs of the length (micrometers) of GBM95 (c) and GBM02 (e), and representative graphs of total number of GBM95 (d) and GBM02 (f) cells are shown. Results represent mean \pm SEM of three independent experiments, each performed in duplicate $(* \mathrm{p}<0.05 ; * * \mathrm{p}$ $<0.01 ; * * * p<0.001)$. Scale bar: $50 \mu \mathrm{m}$.

50 and $100 \mu \mathrm{M}$ ) for 24 and 48 hours (Fig. 6a,b). Diosmin at $50 \mu \mathrm{M}$ increased GBM95 cell death by $47.5 \%$ after a 24 -hour treatment and by $31.1 \%$ after a 48 -hour treatment (Fig. 6c). A similar effect was observed for GBM02 cells, as diosmin increased cell death by $27.5 \%$ after 24 and 48 -hour treatments (Fig. 6e). Subsequently, cleaved caspase-3 immunostaining was performed to understand whether cell death was being triggered by caspasedependent apoptosis. A 48-hour treatment with 100 $\mu \mathrm{M}$ diosmin increased the expression of cleaved caspase-3 in GBM95 and GBM02 cells (Fig. 6a, b). We noticed that $5 \%$ of GBM95 cells (Fig. 6d) and 11\% of GBM02 cells (Fig. 6f) expressed cleaved caspase-3, suggesting that diosmin causes apoptosis by activating the caspase pathway. In summary, these results indicated that diosmin induced GBM95 and GBM02 cell death by cleaved caspase-3-dependent apoptosis. 

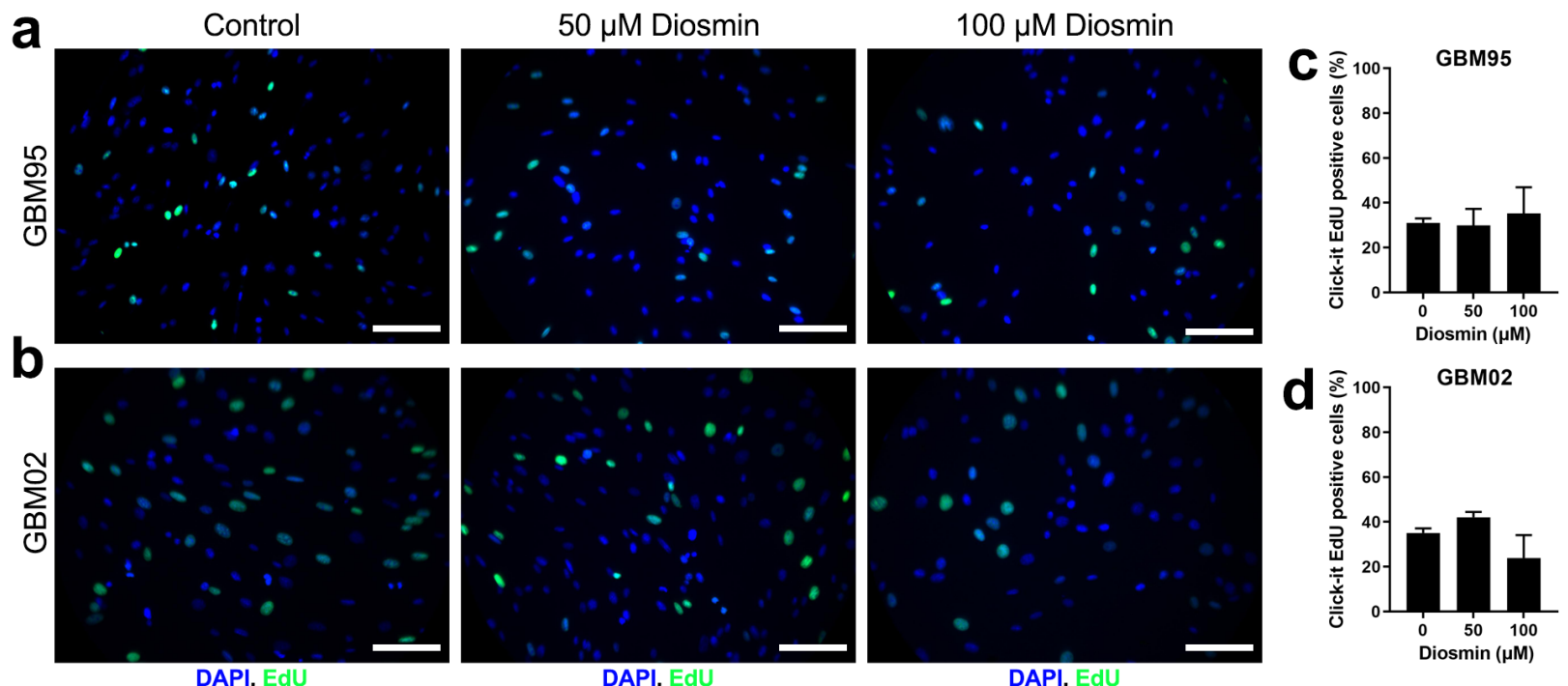

Figure 5 - Diosmin did not reduce GBM95 and GBM02 proliferation. Cell proliferation was evaluated by EdU incorporation. Glioblastoma cells were exposed to diosmin (at 50 and $100 \mu \mathrm{M}$ ) for 48 hours. DMSO was used as control. Representative microscopy images of GBM95 (a) and GBM02 (c) stained with EdU (green) and the quantification of GBM95 (b) and GBM02 (d) proliferative cells labeled by EdU are shown. Results represent mean \pm SEM of three independent experiments, each performed in duplicate. No statistical significance $(\mathrm{p}<0.05)$ was observed. Scale bar: $50 \mu \mathrm{m}$.

In Silico ANALYSIS SUGGESTS THAT THE ACTIVE COMPONENT OF DIOSMIN CAN REACH THE CNS

Intestinal bacteria hydrolyze diosmin to its flavone aglycone, named diosmetin, which is then absorbed (Lyseng-Williamson and Perry 2003). Diosmetin, which is expected to be the active component of diosmin, must in turn reach the central nervous system (CNS). Therefore, we evaluated the ability of diosmetin to cross the blood-brain barrier (BBB) and reach the CNS by using four different in silico parameters: $(i)$ the CNS Multiparameter Optimization (CNS MPO) algorithm, (ii) a binary parameter of brain penetration (BP), (iii) a brain/ blood partition coefficient $(\log \mathrm{BB}),(i v)$ and the probability of being a P-glycoprotein substrate (PgpS).

The CNS MPO algorithm ( $i$ ) is based on six physicochemical properties: $(a)$ lipophilicity, measured by the partition coefficient $(\log \mathrm{P})$; (b) distribution coefficient at $\mathrm{pH} 7.4(\log \mathrm{D}) ;(c)$ molecular weight $(\mathrm{MW}) ;(d)$ topological polar surface area (TPSA); (e) number of hydrogen bond donors $(\mathrm{HBD})$; and $(f)$ ionization constant $(\mathrm{pKa})$ for the most basic center (Wager et al. 2016). All the 6 properties used in the CNS MPO algorithm were calculated on ADMET Predictor ${ }^{\mathrm{TM}}$ software. The total CNS MPO score ranges from 0 to 6 , and the higher the score, the greater the probability of a certain molecule to cross the BBB (Wager et al. 2016). Most CNS-acting drugs have a score $\geq 4.0$ (Wager et al. 2016). Diosmetin had a score of 4.71, which suggests it can cross the BBB.

The BP parameter (ii) simply predicts whether a molecule is able to cross the BBB. The $\log B \mathrm{~B}$ parameter (iii) predicts whether a molecule will be retained in the CNS once it gets in. The PgpS parameter $(i v)$ predicts whether a molecule will be transported back from the CNS to the bloodstream by P-glycoprotein (Pgp), which would impair the distribution to the CNS. The results for these three parameters were provided directly by ADMET Predictor $^{\mathrm{TM}}$ software. Diosmetin was predicted to have low permeability through the BBB. However, its $\log \mathrm{BB}$ value was -0.81 , which is higher than the minimum value of -1.0 for CNS-acting drugs (information provided in the software manual). 

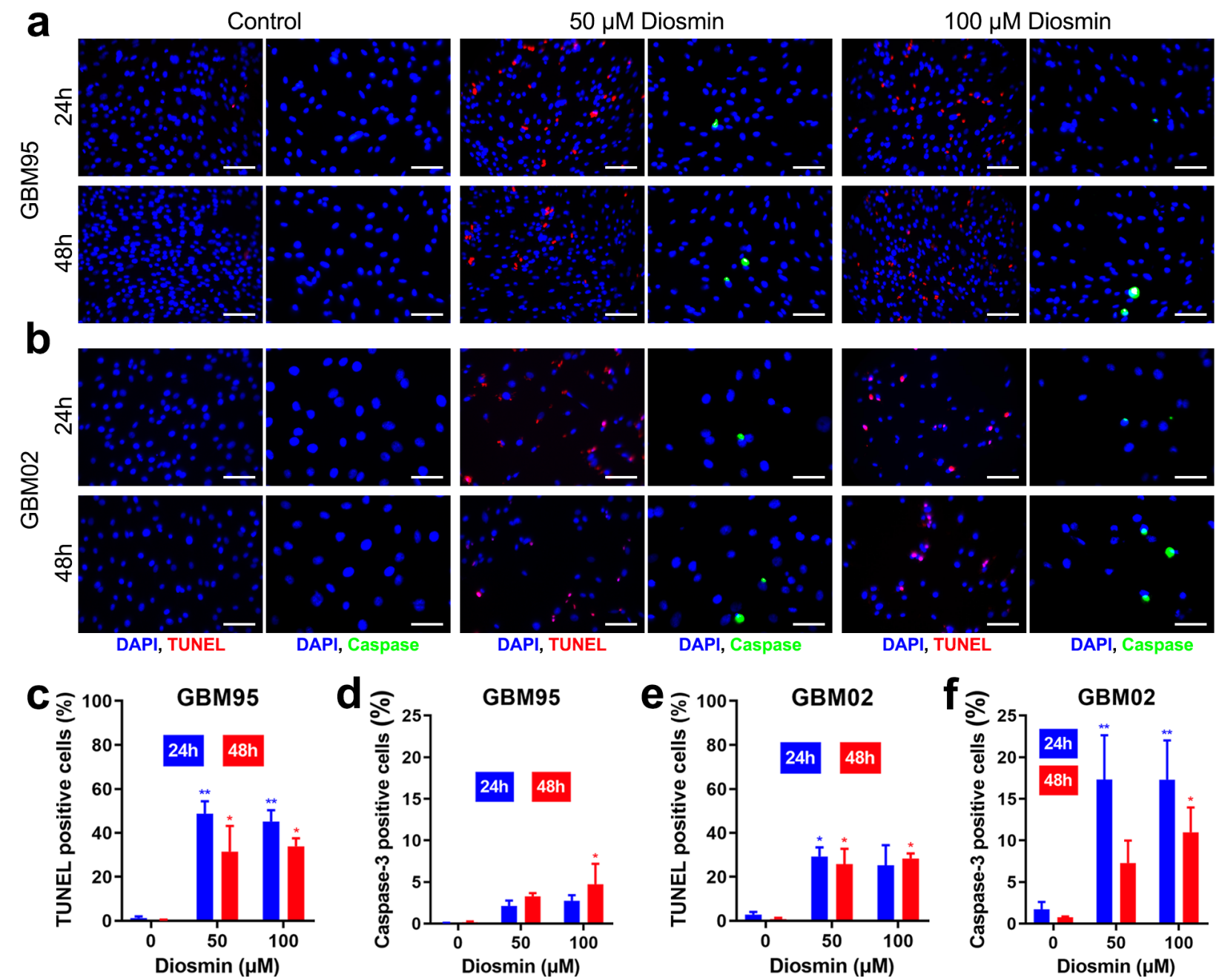

DAPI, TUNEL

DAPI, Caspase
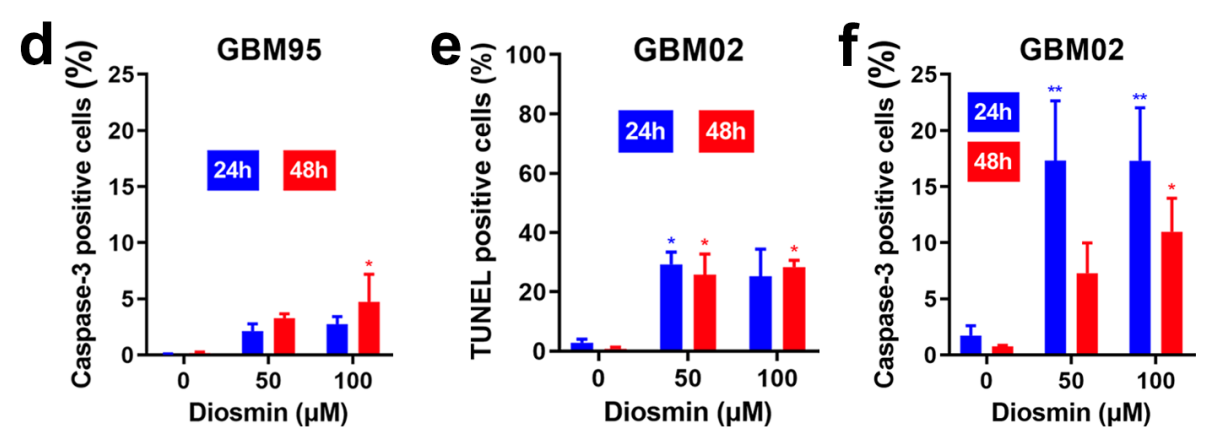

Figure 6 - Diosmin induced glioblastoma cells death by cleaved caspase-3 dependent apoptosis. It was evaluated whether diosmin treatment (at 50 and $100 \mu \mathrm{M}$ ) for 24 and 48 hours could induce glioblastoma cell death by TUNEL assay. Immunostaining for cleaved caspase-3 was performed to evaluate whether cell death occurred by caspase-dependent apoptosis. DMSO was used as control. Representative microscope images of GBM95 (a) and GBM02 (d) stained with TUNEL (red) and cleaved caspase-3 (green) and representative graphs of GBM95 (c, d) and GBM02 (e, f) cell death assessed by TUNEL and cleaved caspase-3 staining, respectively, are shown. Results represent mean \pm SEM of three independent experiments, each performed in duplicate $(* \mathrm{p}<0.05 ; * * \mathrm{p}<0.01)$. Scale bar: $50 \mu \mathrm{m}$.

Diosmetin was also predicted not to undergo PgPmediated efflux. In summary, these results suggest that, after oral administration of diosmin, its flavone aglycone would likely reach the CNS.

\section{DISCUSSION}

Since there is no effective treatment for glioblastoma so far, the discovery of new strategies and targeted agents are emerging (Li et al. 2017). In this context, flavonoids can act against different events associated with cancer (Batra and Sharma 2013). In vitro experiments have shown that flavonoids can inhibit glioblastoma proliferation and/or induce apoptosis (Kim et al. 2016, Li et al. 2017, Santos et al. 2015). Apigenin and luteolin, like diosmin, belong to the flavone class and are known for their anti-cancer properties (Chen et al. 2016b, Singh et al. 2014). In vitro studies have shown that apigenin induces apoptosis in U373, T98G, and U87MG cells (Das et al. 2010, Kim et 
al. 2016) and that luteolin decreases the viability of U87MG and T98G cells (Chakrabarti and Ray 2016). Previous work demonstrated that the flavonoids apigenin, luteolin, and silibinin were able to induce apoptosis in glioblastoma cells and to reduced their proliferation (Chakrabarti and Ray 2015, Stump et al. 2017).

In this study, we evaluated the potential use of diosmin in the therapy for human glioblastoma using cell-based assays and a complementary in silico analysis. Diosmin caused a significant decrease in the viability of GBM95, GBM02, and U87MG cells, especially after 48-hour incubation. Notably, diosmin did not significantly change the viability of healthy human astrocytes, indicating that it acts selectively on tumor cells. A similar selectivity was observed for rat carcinoma cells, wherein diosmin reduced the viability of HA22T cells without impairing the viability of healthy liver cells (Dung et al. 2012).

The viability of glioblastoma cells was evaluated after the combination of diosmin with TMZ. Previous studies demonstrated that TMZ acts against glioblastoma cells at a minimum concentration of $200 \mu \mathrm{M}$ (Matias et al. 2017, Zhang et al. 2017). Recently, our group calculated TMZ potency against GBM02 and GBM95 cells, evidencing $\mathrm{IC}_{50}$ values above $600 \mu \mathrm{M}$ (da Silva et al. 2019). The cytotoxicity of TMZ is associated with the formation of $\mathrm{O}^{6}$-methylguanine in DNA that mispairs with thymine during DNA replication (Fan et al. 2013). Consequently, glioma cells respond by undergoing G2/M arrest and die by autophagy or apoptosis (Fan et al. 2013, Kanzawa et al. 2004). Moreover, recent studies suggested that the combination with natural compounds could increase TMZ efficiency. Quercetin, for example, was able to sensitize glioblastoma cells to TMZ, reducing treatment resistance (Hu et al. 2016, JakubowiczGil et al. 2013, Sang et al. 2014). Quercetin and TMZ together induced a potent apoptotic effect in glioblastoma cells by endoplasmic reticulum stress, followed by activation of the mitochondrial death pathway (Jakubowicz-Gil et al. 2013).

Although other studies demonstrated some benefits of the association of TMZ with flavonoids, our results showed that the mixed treatment is less efficient than that with diosmin alone, indicating that no synergistic effect takes place. However, the combination was more effective than the treatment with TMZ alone, perhaps because TMZ is not so effective in cell culture (da Silva et al. 2019). Even though TMZ is the clinical chemotherapy choice for glioblastoma treatment, concentrations above $600 \mu \mathrm{M}$ are needed for a significant in vitro effect (da Silva et al. 2019). Thus, following experiments were done only with diosmin at the intermediate concentrations of 50 and $100 \mu \mathrm{M}$, which were effective against GBM95 and GBM02 cells.

Diosmin also caused GBM95 and GBM02 cells to have their sizes reduced and to be less elongated and more polygonal. Other flavonoids can induce similar morphological changes (Isoda et al. 2014, Touil et al. 2009). Morphological alterations of glioblastoma cells induced by natural compounds were previously associated with cytotoxic effects, reduction in cell migration, and inhibition of tumor progression (Matias et al. 2017, Santos et al. 2015). Chrysin, kaempferol, apigenin, and quercetin have been shown to induce cytoplasmic retraction in glioblastoma GL-15, which has been mentioned as one of the features of cells which were dying by apoptosis (Santos et al. 2015).

Our morphological analysis suggested that diosmin decreased GBM95 and GBM02 cellularity. Reduction in cell number is closely linked to inhibition of proliferation and death induction (Ouhtit et al. 2013). However, diosmin did not show any anti-proliferative effect. This could be explained by glioblastoma high proliferation rate (Faria et al. 2006, Santos et al. 2015), which makes the therapy even more difficult. Since diosmin did not reduce GBM95 and GBM02 proliferation, we evaluated whether the decrease in viability and 
cytoskeleton alterations were associated with a specific death process, and we found that diosmin caused a significant increase in DNA fragmentation in GBM95 and GBM02 cells, leading to increased cell death. We also demonstrated that cell death was associated with a caspase-dependent apoptosis. Diosmin increased the expression of cleaved caspase-3, a cysteine protease considered a marker of apoptosis, as its activity is required for biochemical and morphological events associated with cell death (Crowley and Waterhouse 2016). Other studies demonstrated that diosmin could induce apoptosis in breast, prostate, carcinoma, and melanoma cancer cells under similar treatment conditions. The apoptosis induced by diosmin has also been linked to an increase in reactive oxidative species (ROS) and to chromosomal DNA damage and methylation (Lewinska et al. 2015). In the present study, the inhibition of tumor progression via apoptosis by diosmin is remarkable, especially considering the capacity of glioblastoma to evade this process (Stump et al. 2017).

It is very interesting to have such a significant effect against glioblastoma using a flavonoid, as these natural compounds are less expensive and have much lower toxicity and side effects compared to classical chemotherapy (Alves et al. 2017). Because diosmin is absorbed as diosmetin after oral administration (Lyseng-Williamson and Perry 2003), we performed an in silico evaluation of the aglycone accessibility to the CNS and found that it could likely cross the BBB. Nevertheless, it has been previously described that diosmin may also be directly absorbed from the digestive tract (Chen et al. 2019), while numerous works have reported that free diosmetin and diosmetin glycosidesincluding diosmin - are able to reach the CNS, as they have been shown to possess sedative effects (Fernández et al. 2006), antiautistic effects (Tan et al. 2013), central anti-hyperalgesic effects (Carballo-Villalobos et al. 2018), and memoryenhancing and anxiolytic-like effects (Oliveira et al. 2018). Furthermore, the brain penetration of drugs is facilitated in glioblastoma, since the high rate of parenchyma infiltration causes vascular fragility and weakens the BBB (Dubois et al. 2014). The permeability could also be enhanced by nanostructure delivery systems (Renukuntla et al. 2013). Additionally, it is also possible to administer diosmin directly into the patient's brain after tumor removal (Perry 2007). This strategy has already been used in glioblastoma patients who received local administration of carmustine to guarantee direct drug arrival and avoid solubility problems (Akiyama et al. 2018).

In summary, we evaluated the antitumor effects of diosmin against different glioblastoma cell lines. The results showed that this flavonoid is a promising natural compound against glioblastoma. However, further studies are needed to better understand diosmin mechanism of action to design new protocols for its application in the treatment of glioblastoma. Since diosmin is already in clinical use and is considered safe, acute toxicity studies would not be required prior to investigating diosmin efficacy in vivo.

\section{ACKNOWLEDGMENTS}

We thank Fabio Jorge da Silva and Rosenilde Holanda for technical assistance. This work was supported by grants from the Conselho Nacional de Desenvolvimento Científico e Tecnológico (CNPq), Coordenação de Aperfeiçoamento de Pessoal de Nível Superior (CAPES) Finance Code 001, and Fundação Carlos Chagas Filho de Amparo à Pesquisa do Estado do Rio de Janeiro (FAPERJ). The authors declare to have no conflict of interest.

\section{AUTHOR CONTRIBUTIONS}

L.F.R. designed the research; J.M.S. was involved in all aspects of the experimental design, data collection, analysis and interpretation. B.M.F. did the in vitro assays. J.M.S., B.M.F. and L.M.A. 
prepared the figures. L.M.A. performed the in silico analysis. S.V.A.L. and J.M.S. provided the cell lines. A.G.S. provided the purified diosmin. J.M.S., L.M.A., Y.C. and L.F.R. wrote the manuscript. All authors read and approved the final manuscript.

\section{REFERENCES}

AKIYAMA Y, KIMURA Y, ENATSU R, MIKAMI T, WANIBUCHI M AND MIKUNI N. 2018. Advantages and Disadvantages of Combined Chemotherapy with Carmustine Wafer and Bevacizumab in Patients with Newly Diagnosed Glioblastoma: A Single-Institutional Experience. World Neurosurg 113: e508-e514.

ALI R, MIRZA Z, ASHRAF GMD, KAMAL MA, ANSARI SA, DAMANHOURI GA, ABUZENADAH AM, CHAUDHARY AG AND SHEIKH IA. 2012. New anticancer agents: recent developments in tumor therapy. Anticancer Res 32: 2999-3005.

ALLEN M, BJERKE M, EDLUND H, NELANDER S AND WESTERMARK B. 2016. Origin of the U87MG glioma cell line: Good news and bad news. Sci Transl Med 8: 354 re3.

ÁlVAREZ N, VICENTE V AND MARTÍNEZ C. 2009. Synergistic Effect of Diosmin and Interferon- $\alpha$ on Metastatic Pulmonary Melanoma. Cancer Biother Radiopharm 24: 347-352.

ALVES DR ET AL. 2017. Flavonoid Composition and Biological Activities of Ethanol Extracts of Caryocar coriaceum Wittm., a Native Plant from Caatinga Biome. Evid Based Complement Alternat Med 2017: 6834218.

BATRA P AND SHARMA AK. 2013. Anti-cancer potential of flavonoids: recent trends and future perspectives. 3 Biotech 3(6): 439-459.

CARBALLO-VILLALOBOS AI, GONZÁLEZ-TRUJANO ME, PELLICER F, ALVARADO-VÁSQUEZ N AND LÓPEZ-MUÑOZ FJ. 2018. Central and peripheral antihyperalgesic effects of diosmin in a neuropathic pain model in rats. Biomed Pharmacother 97: 310-320.

CHAHAR MK, SHARMA N, DOBHAL MP AND JOSHI YC. 2011. Flavonoids: A versatile source of anticancer drugs. Pharmacogn Rev 5: 1-12.

CHAKRABARTI M AND RAY SK. 2015. Synergistic anti-tumor actions of luteolin and silibinin prevented cell migration and invasion and induced apoptosis in glioblastoma SNB19 cells and glioblastoma stem cells. Brain Res 1629: 85-93.

CHAKRABARTI M AND RAY SK. 2016. Anti-tumor activities of luteolin and silibinin in glioblastoma cells: Overexpression of miR-7-1-3p augmented luteolin and silibinin to inhibit autophagy and induce apoptosis in glioblastoma in vivo. Apoptosis 21: 312-328.
CHEN G, LI X, SALERI F AND GUO M. 2016a. Analysis of Flavonoids in Rhamnus davurica and Its Antiproliferative Activities. Molecules 21: E1275.

CHEN X, WU M, LI D AND YOU J. 2016b. Apigenin inhibits glioma cell growth through promoting microRNA-16 and suppression of BCL-2 and nuclear factor- $\kappa \mathrm{B} / \mathrm{MMP}-9$. Mol Med Rep 14: 2352-2358.

CHEN X, XU L, GUO S, WANG Z, JIANG L, WANG F, ZHANG J AND LIU B. 2019. Profiling and comparison of the metabolites of diosmetin and diosmin in rat urine, plasma and feces using UHPLC-LTQ-Orbitrap MS ${ }^{\mathrm{n}}$. J Chromatogr B Analyt Technol Biomed Life Sci 1124: 5871.

CHOI J, LEE DH, PARK SY AND SEOL JW. 2019. Diosmetin inhibits tumor development and block tumor angiogenesis in skin cancer. Biomed Pharmacother 117: 109091.

CROWLEY LC AND WATERHOUSE NJ. 2016. Detecting Cleaved Caspase-3 in Apoptotic Cells by Flow Cytometry. Cold Spring Harb Protoc 2016: 958-962.

DA SILVA VD, DE FARIA BM, COLOMBO E, ASCARI L, FREITAS GPA, FLORES LS, CORDEIRO Y, ROMÃO L AND BUARQUE CD. 2019. Design, synthesis, structural characterization and in vitro evaluation of new 1,4-disubstituted-1,2,3-triazole derivatives against glioblastoma cells. Bioorg Chem 83: 87-97.

DAS A, BANIK NLAND RAY SK. 2010. Flavonoids activated caspases for apoptosis in human glioblastoma T98G and U87MG cells but not in human normal astrocytes. Cancer 116: 164-176.

DUBOIS LG ET AL. 2014. Gliomas and the vascular fragility of the blood brain barrier. Front Cell Neurosci 8: 418.

DUNG TD ET AL. 2012. PP2A mediates diosmin p53 activation to block HA22T cell proliferation and tumor growth in xenografted nude mice through PI3K-AktMDM2 signaling suppression. Food Chem Toxicol 50: 1802-1810.

EL-SHAFAE AM AND EL-DOMIATY MM. 2001. Improved LC methods for the determination of diosmin and/or hesperidin in plant extracts and pharmaceutical formulations. J Pharm Biomed Anal 26: 539-545.

ELMORE S. 2007. Apoptosis: a review of programmed cell death. Toxicol Pathol 35: 495-516.

ERICES JI, TORRES Á, NIECHI I, BERNALES I AND QUEZADA C. 2018. Current natural therapies in the treatment against glioblastoma. Phytother Res 32: 21912201.

FAN CH, LIU WL, CAO H, WEN C, CHEN L AND JIANG G. 2013. O6-methylguanine DNA methyltransferase as a promising target for the treatment of temozolomideresistant gliomas. Cell Death Dis 4: e876.

FANTINI M, BENVENUTO M, MASUELLI L, FRAJESE GV, TRESOLDI I, MODESTI A AND BEI R. 2015. In vitro and in vivo antitumoral effects of combinations 
of polyphenols, or polyphenols and anticancer drugs: perspectives on cancer treatment. Int J Mol Sci 16: 92369282.

FARIA J ET AL. 2006. Interactive properties of human glioblastoma cells with brain neurons in culture and neuronal modulation of glial laminin organization. Differentiation 74: 562-572.

FERNÁNDEZ SP, WASOWSKI C, LOSCALZO LM, GRANGER RE, JOHNSTON GAR, PALADINI AC AND MARDER M. 2006. Central nervous system depressant action of flavonoid glycosides. Eur J Pharmacol 539: 168176.

GARCIA C. 2014. The orthotopic xenotransplant of human glioblastoma successfully recapitulates glioblastomamicroenvironment interactions in a non-immunosuppressed mouse model. BMC Cancer 14: 923.

HITZENBERGER G. 1997. Therapeutic effectiveness of flavonoids illustrated by daflon $500 \mathrm{mg}$. Wien Med Wochenschr 147: 409-412.

HU J, WANG J, WANG G, YAO Z AND DANG X. 2016. Pharmacokinetics and antitumor efficacy of DSPEPEG2000 polymeric liposomes loaded with quercetin and temozolomide: Analysis of their effectiveness in enhancing the chemosensitization of drug-resistant glioma cells. Int $\mathbf{J}$ Mol Med 37: 690-702.

ISODA H, MOTOJIMA H, ONAGA S, SAMET I, VILLAREAL MO AND HAN J. 2014. Analysis of the erythroid differentiation effect of flavonoid apigenin on K562 human chronic leukemia cells. Chem Biol Interact 220: 269-277.

JAKUBOWICZ-GIL J, LANGNER E, BĄDZIUL D, WERTEL I AND RZESKI W. 2013. Apoptosis induction in human glioblastoma multiforme T98G cells upon temozolomide and quercetin treatment. Tumour Biol 34: 2367-2378.

KANZAWA T, GERMANO IM, KOMATA T, ITO H, KONDO Y AND KONDO S. 2004. Role of autophagy in temozolomide-induced cytotoxicity for malignant glioma cells. Cell Death Differ 11: 448-457.

KIM B, JUNG N, LEE S, SOHNG JK AND JUNG HJ. 2016. Apigenin Inhibits Cancer Stem Cell-Like Phenotypes in Human Glioblastoma Cells via Suppression of c-Met Signaling. Phyther Res 30: 1833-1840.

KOOSHA S, MOHAMED Z, SINNIAH A AND ALSHAWSH MA. 2019. Evaluation of Anti-Tumorigenic Effects of Diosmetin against Human Colon Cancer Xenografts in Athymic Nude Mice. Molecules 24: E2522.

LAURENT R, GILLY R AND FRILEUX C. 1988. Clinical evaluation of a venotropic drug in man. Example of Daflon 500 mg. Int Angiol 7: 39-43.

LEWINSKA A, ADAMCZYK-GROCHALA J, KWASNIEWICZ E, DEREGOWSKA A AND WNUK M. 2017. Diosmin-induced senescence, apoptosis and autophagy in breast cancer cells of different p53 status and ERK activity. Toxicol Lett 265: 117-130.

LEWINSKA A, SIWAK J, RZESZUTEK I AND WNUK M. 2015. Diosmin induces genotoxicity and apoptosis in DU145 prostate cancer cell line. Toxicol Vitr 29: 417-425.

LI J, DONG Y, HAO G, WANG B, WANG J, LIANG Y, LIU Y, ZHEN E, FENG D AND LIANG G. 2017. Naringin suppresses the development of glioblastoma by inhibiting FAK activity. J Drug Target 25: 41-48.

LI Q, MIAO Z, WANG R, YANG J AND ZHANG D. 2019. Hesperetin Induces Apoptosis in Human Glioblastoma Cells via p38 MAPK Activation. Nutr Cancer 11: 1-8.

LIEBERMAN F. 2017. Glioblastoma update: molecular biology, diagnosis, treatment, response assessment, and translational clinical trials. F1000Res 6: 1892.

LYSENG-WILLIAMSON KA AND PERRY CM. 2003. Micronised purified flavonoid fraction: A review of its use in chronic venous insufficiency, venous ulcers and haemorrhoids. Drugs 63: 71-100.

MAHER EA, FURNARI FB, BACHOO RM, ROWITCH DH, LOUIS DN AND CAVENEE WK AND DEPINHO RA. 2001. Malignant glioma: Genetics and biology of a grave matter. Genes Dev 15: 1311-1333.

MATIAS D. 2017. Dual treatment with shikonin and temozolomide reduces glioblastoma tumor growth, migration and glial-to-mesenchymal transition. Cell Oncol 40: 247-261.

MEYER OC. 1994. Safety and security of Daflon $500 \mathrm{mg}$ in venous insufficiency and in hemorrhoidal disease. Angiology 45: 579-584.

MOONEY J, BERNSTOCK JD, ILYAS A, IBRAHIM A, YAMASHITA D, MARKERT JM AND NAKANO I. 2019. Current Approaches and Challenges in the Molecular Therapeutic Targeting of Glioblastoma. World Neurosurg 129: 90-100.

OLIVEIRA DR, TODO AH, RÊGO GM, CERUTTI JM, CAVALHEIRO AJ, RANDO DGG AND CERUTTI SM. 2018. Flavones-bound in benzodiazepine site on GABAA receptor: Concomitant anxiolytic-like and cognitive-enhancing effects produced by Isovitexin and 6-C-glycoside-Diosmetin. Eur J Pharmacol 831: 77-86.

OUHTIT AETAL. 2013. Simultaneous inhibition of cell-cycle, proliferation, survival, metastatic pathways and induction of apoptosis in breast cancer cells by a phytochemical super-cocktail: genes that underpin its mode of action. J Cancer 4: 703-715.

PERRY J, CHAMBERS A, SPITHOFF K AND LAPERRIERE N. 2007. Gliadel wafers in the treatment of malignant glioma: a systematic review. Curr Oncol 14: 189-194.

PERUMAL S, LANGESHWARAN K, SELVARAJ J, PONNULAKSHMI R, SHYAMALADEVI B AND BALASUBRAMANIAN MP. 2018. Effect of diosmin on apoptotic signaling molecules in N-nitrosodiethylamine- 
induced hepatocellular carcinoma in experimental rats. Mol Cell Biochem 449: 27-37.

RAMELET AA. 2001. Clinical benefits of Daflon $500 \mathrm{mg}$ in the most severe stages of chronic venous insufficiency. Angiology 52: S49-S56.

RENUKUNTLA J, VADLAPUDI AD, PATEL A, BODDU SH AND MITRA AK. 2013. Approaches for enhancing oral bioavailability of peptides and proteins. Int $\mathrm{J}$ Pharm 447: 75-93.

SAK K. 2014. Cytotoxicity of dietary flavonoids on different human cancer types. Pharmacogn Rev 8: 122-146.

SANG DP, LI RJ AND LAN Q. 2014. Quercetin sensitizes human glioblastoma cells to temozolomide in vitro via inhibition of Hsp27. Acta Pharmacol Sin 35: 832-838.

SANTOS BL ET AL. 2015. Flavonoids suppress human glioblastoma cell growth by inhibiting cell metabolism, migration, and by regulating extracellular matrix proteins and metalloproteinases expression. Chem Biol Interact 242: 123-138.

SIEGELIN MD, GAISER T, HABEL A AND SIEGELIN Y. 2009. Daidzein overcomes TRAIL-resistance in malignant glioma cells by modulating the expression of the intrinsic apoptotic inhibitor, bcl-2. Neurosci Lett 454: 223-228.

SINGH M, KAUR M AND SILAKARI O. 2014. Flavones: An important scaffold for medicinal chemistry. Eur J Med Chem 84: 206-239.

SRINIVASAN S AND PARI L. 2012. Ameliorative effect of diosmin, a citrus flavonoid against streptozotocinnicotinamide generated oxidative stress induced diabetic rats. Chem Biol Interact 195: 43-51.

STUMP TA, SANTEE BN, WILLIAMS LP, KUNZE RA, HEINZE CE, HUSEMAN ED, GRYKA RJ, SIMPSON
DS AND AMOS S. 2017. The antiproliferative and apoptotic effects of apigenin on glioblastoma cells. J Pharm Pharmacol 69: 907-916.

TAN J, LUO D AND SHYTLE RD. 2013. Luteolin and diosmin/diosmetin as novel STAT3 inhibitors for treating autism. Patent US8778894B2.

TOUIL YS, FELLOUS A, SCHERMAN D AND CHABOT GG. 2009. Flavonoid-induced morphological modifications of endothelial cells through microtubule stabilization. Nutr Cancer 61: 310-321.

WAGER TT, HOU X, VERHOEST PR AND VILLALOBOS A. 2016. Central Nervous System Multiparameter Optimization Desirability: Application in Drug Discovery. ACS Chem Neurosci 7: 767-775.

WANG C, LI S, REN H, SHENG Y, WANG T, LI M, ZHOU Q, HE H AND LIU C. 2019. Anti-Proliferation and ProApoptotic Effects of Diosmetin via Modulating Cell Cycle Arrest and Mitochondria-Mediated Intrinsic Apoptotic Pathway in MDA-MB-231 Cells. Med Sci Monit 25: 4639-4647.

WÜRTH R, BARBIERI F AND FLORIO T. 2014. New molecules and old drugs as emerging approaches to selectively target human glioblastoma cancer stem cells. Biomed Res Int 2014: 126586.

YARMOLINSKY L, BUDOVSKY A, BEN-SHABAT S, KHALFIN B, GORELICK J, BISHITZ Y, MILOSLAVSKI R AND YARMOLINSKY L. 2019. Recent Updates on the Phytochemistry and Pharmacological Properties of Phlomis viscosa Poiret. Rejuvenation Res 22: 282-288.

ZHANG P ET AL. 2017. Rutin increases the cytotoxicity of temozolomide in glioblastoma via autophagy inhibition. $\mathrm{J}$ Neurooncol 132: 393-400. 
An Acad Bras Cienc (2020) 92(1): e201901031 DOI 10.1590/0001-37652019201901031

Anais da Academia Brasileira de Ciências | Annals of the Brazilian Academy of Sciences

Printed ISSN 0001-3765 I Online ISSN 1678-2690

www.scielo.br/aabc | www.fb.com/aabcjournal

\section{ERRATUM}

In the article Diosmin induces caspase-dependent apoptosis in human glioblastoma cells, with DOI number: http://dx.doi. org/10.1590/0001-3765201920191031, published in the journal Anais da Academia Brasileira de Ciências, 91(4): e20191031, page 9

Reads:
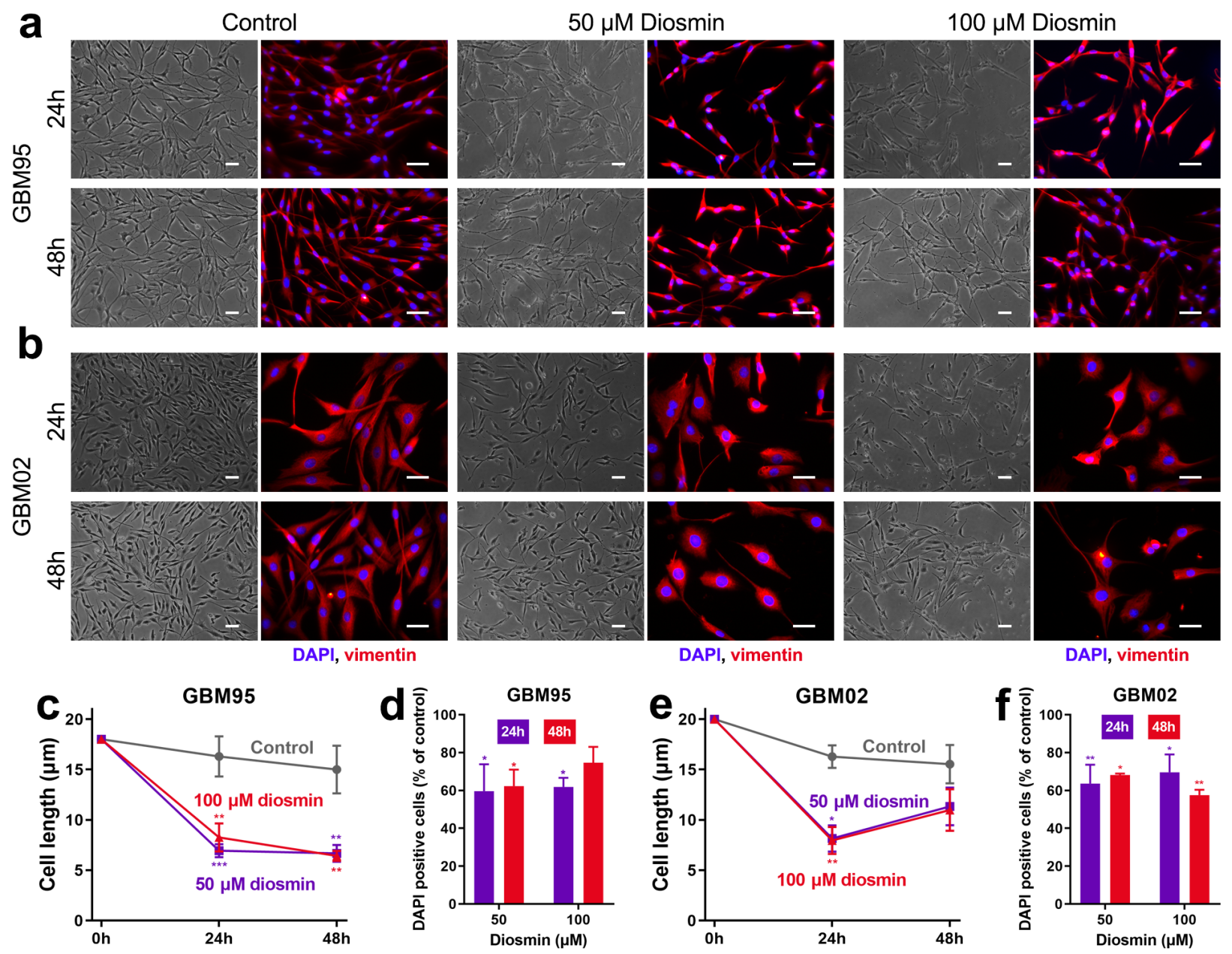

Figure 4 - Diosmin induced morphological alterations and reduced GBM95 and GBM02 cellularity. Phase contrast (gray scale) and vimentin immunostaining (red) were used to evaluate cell morphology and cytoskeleton. DAPI (blue) was used for nuclei staining to count the total number of cells. GBM95 and GBM02 were treated with diosmin (at 50 and $100 \mu \mathrm{M}$ ) for 24 and 48 hours. DMSO was used as control. Phase contrast and vimentin representative images of GBM95 (a) and GBM02 (b), representative graphs of the length (micrometers) of GBM95 (c) and GBM02 (e), and representative graphs of total number of GBM95 (d) and GBM02 (f) cells are shown. Results represent mean \pm SEM of three independent experiments, each performed in duplicate $\left({ }^{*} p<0.05 ; * * p<0.01 ; * * * p\right.$ $<0.001)$. Scale bar: $50 \mu \mathrm{m}$. 


\section{Should read:}
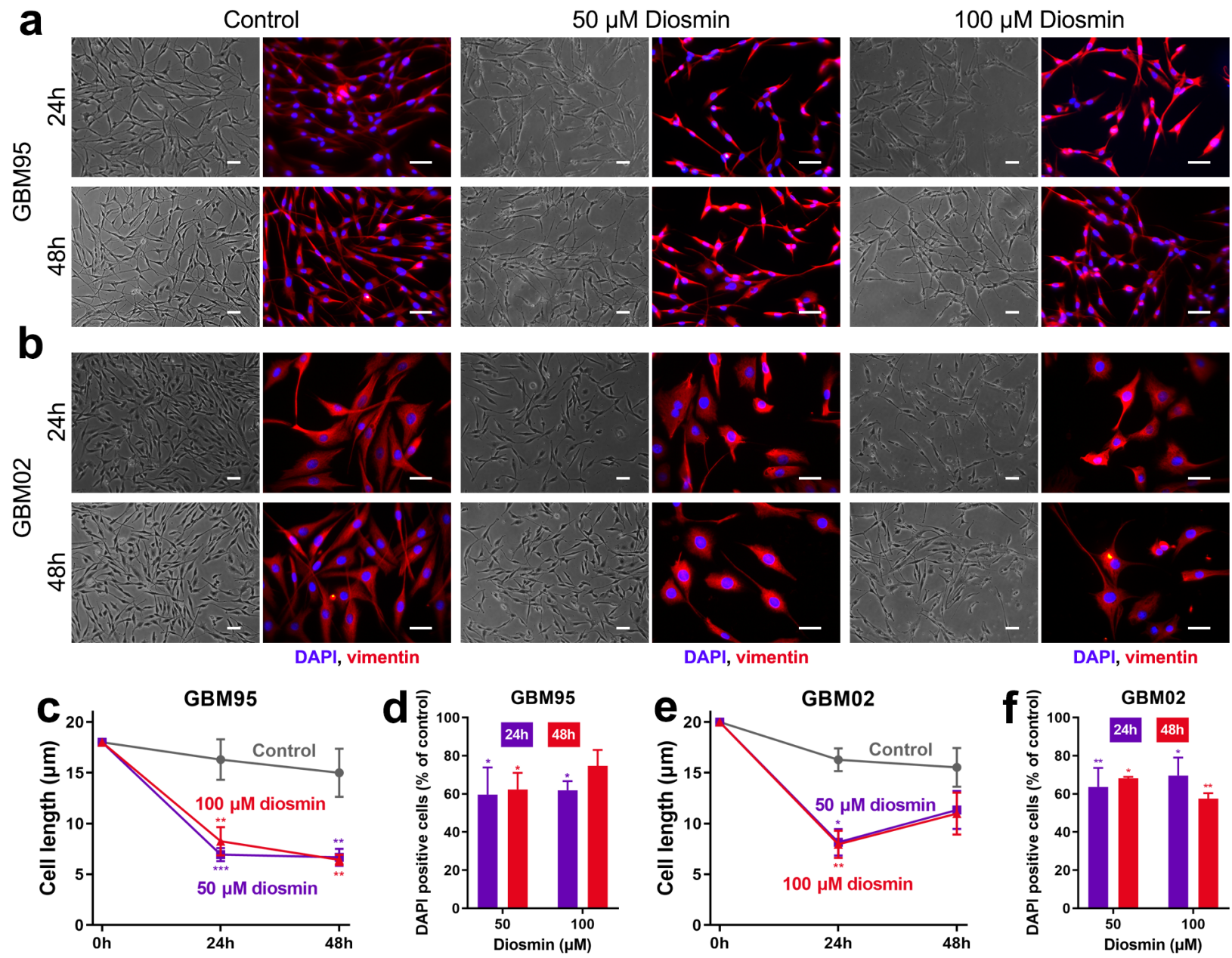

Figure 4 - Diosmin induced morphological alterations and reduced GBM95 and GBM02 cellularity. Phase contrast (gray scale) and vimentin immunostaining (red) were used to evaluate cell morphology and cytoskeleton. DAPI (blue) was used for nuclei staining to count the total number of cells. GBM95 and GBM02 were treated with diosmin (at 50 and $100 \mu \mathrm{M}$ ) for 24 and 48 hours. DMSO was used as control. Phase contrast and vimentin representative images of GBM95 (a) and GBM02 (b), representative graphs of the length (micrometers) of GBM95 (c) and GBM02 (e), and representative graphs of total number of GBM95 (d) and GBM02 (f) cells are shown. Results represent mean \pm SEM of three independent experiments, each performed in duplicate $\left({ }^{*} p<0.05 ;{ }^{* *} p<0.01 ;{ }^{* * *} p\right.$ $<0.001)$. Scale bar: $50 \mu \mathrm{m}$.

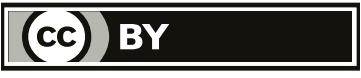

